\title{
DETERMINING AN OPTIMAL SUPPLY CHAIN STRATEGY
}

\author{
INTAHER M AMBE \\ Ambeim@unisa.ac.za \\ Department of Business Management \\ University of South Africa (Unisa)
}

\begin{abstract}
In today's business environment, many companies want to become efficient and flexible, but have struggled, in part, because they have not been able to formulate optimal supply chain strategies. Often this is as a result of insufficient knowledge about the costs involved in maintaining supply chains and the impact of the supply chain on their operations. Hence, these companies find it difficult to manufacture at a competitive cost and respond quickly and reliably to market demand. Mismatched strategies are the root cause of the problems that plague supply chains, and supply-chain strategies based on a one-size-fits-all strategy often fail. The purpose of this article is to suggest instruments to determine an optimal supply chain strategy. This article, which is conceptual in nature, provides a review of current supply chain strategies and suggests a framework for determining an optimal strategy.
\end{abstract}

\section{INTRODUCTION}

Supply chain management (SCM) is a challenging concept, with elusive goals, and is a critical success factor for today's businesses (Qi, Boyer \& Zhao, 2009: 667; Duarte \& Machado, 2011: 328). As a result of the importance of SCM, companies are searching for ways to improve their performance (El-Tawy \& Gallear, 2011: 801), make strategic decisions, and develop competitive strategies that add value in the eyes of customers (Lee, 2002: 105; Ambe \& Badenhorst-Weiss, 2011: 337). A supply chain strategy specifies how a firm will achieve its competitive advantages through its supply chain capabilities, such as cost efficiency, response speed and flexibility (Ismail \& Sharifi, 2006: 436). A supply chain strategy also specifies how the manufacturing, purchasing, marketing, and logistics functions work together to support the desired competitive strategy (Qi, Zhao \& Sheu, 2011: 372). It is therefore imperative for supply chain managers to understand customers' needs, and to choose and implement an optimal supply chain strategy to satisfy customer demands.

Two generic supply chain strategies are the lean and the agile strategies (Fisher, 1997; Mason-Jones, Naylor, \& Towill, 2000; Christopher \& Towill, 2001; Yusuf, Gunasekaran, Adeleye \& Sivayoganathan, 2004). Determining an optimal supply chain strategy requires a trade-off between key variables (Ambe \& Badenhorst-Weiss, 2011: 338). According to 
the extremely influential work of Fisher (1997), a company can choose one of these generic strategies based on the nature of their product, and by matching the strategy to the unique characteristics of different products or markets (Christopher \& Towill 2002; Sebastiao \& Golicic 2008). According to Fisher (1997: 107), a supply chain strategy is established based on the product type (functional or innovative products). Lee (2002: 106) asserts that a strategy can be chosen by determining supply and demand characteristics (evolving versus stable supply) (Sebastiao \& Golicic, 2008: 76). Chopra and Meindl (2010: 44) believe that a trade-off between efficiency and responsiveness is required to determine a supply chain strategy (Qi et al., 2011: 372).

Other important criteria for determining a supply chain strategy include products (standard or special); demand (stable or volatile); replenishment lead times (short or long) (Christopher, Peck \& Towill, 2006: 282); the specific 'market winner' criterion (Christopher \& Towill, 2002: 9); the product life cycle (PLC) (Fawcett, Ellram \& Ogden, 2007: 222); and the nature of pushand pull-based supply chains (Simchi-Levi, Kaminsky \& Simchi-Levi, 2003; Diaz, 2005: 65). Moreover, Duarte and Machado (2011: 329) noted that 1) the structure; 2) organisational relationships; and (3) process (Sayuti, 2011: 288) are essential determinants of a supply chain strategy. Narasimhan and Kim (2002: 303) emphasise that the nature of the business, the competitive environment, technology, and product and market characteristics are also fundamental determinants of supply chain strategies (Qi et al., 2009: 673). Agarwal, Shankar and Tiwari (2007: 443) state that information technology, centralised and collaborative planning, and process integration are equally important determinants of an optimal supply chain strategy.

Therefore, there are several factors that can be considered when determining a supply chain strategy (Qi et al., 2009: 667; Ambe \& Badenhorst-Weiss, 2011: 339). Despite these factors, the majority of scholars have emphasised product characteristics when determining supply chain strategies (El-Tawy \& Gallear, 2011: 809). Apart from product characteristics, factors such as core competencies of the organisation; capabilities of the supply chain members; and decision drivers are significant criteria that can be considered when deciding on an optimal supply chain strategy (Chopra \& Meindl, 2010: 63; Sayuti, 2011: 288). Agarwal et al. (2007: 443) stated that the influence of interrelationships has barely been considered in determining supply chain strategies. Hence, there is a need for a comprehensive framework that incorporates the various factors and so provides a tool to decide on how best to manage a supply chain (Qi et al., 2009: 668).

In line with this, the purpose of this article is therefore to: 1) review literature on supply chain strategies and 2) suggest a comprehensive framework for determining an optimal supply chain strategy. The article made use of a conceptual analytical approach. Botha (1989) asserted that a conceptual approach is used in research to outline possible courses 
of action or to present a preferred approach to an idea or thought. The article begins by providing a conceptual (literature) review of supply chain strategies. The purpose of this section is to determine the status quo of supply chain strategies and to identify the criteria that can be used to determine an optimal supply chain strategy. This section is followed by the development of a comprehensive framework for determining a supply chain strategy, as well as relevant practices. In this section, the different characteristics and practices for lean and agile supply chain strategies provide a map for a comprehensive framework.

\section{REVIEW OF SUPPLY CHAIN STRATEGIES}

This section reviews supply chain strategies. It begins by defining supply chain management before examining the various possible strategies and exploring the characteristics that define these strategies.

\section{What is a supply chain strategy?}

In answering this question, we first need to define supply chain management (SCM). SCM can be defined as a set of approaches that efficiently integrate and coordinate the materials, information and financial flows across the supply chain so that merchandise is supplied, produced and distributed in the right quantities, to the right locations, and at the right time, in the most cost-efficient way, while satisfying customer requirements (Hilletofth, 2009: 16; Hugo, Badenhorst-Weiss \& Van Biljon, 2011: 4; Shukla, Garg \& Agarwal, 2011: 2059). The objective of SCM is to achieve a sustainable competitive advantage (Handfield, Monczka, Giuinipero \& Patterson, 2009: 12). A supply chain strategy is part of the overall business strategy, designed around a well-defined basis of competition (innovation, low cost, service, quality) (Hugo, Badenhorst-Weiss \& Van Biljon, 2011: 22). It is integrated with the marketing strategy, customers' needs, the product strategy, and power position (Hugo et al., 2011: 22; Hines, 2006: 33; Klemencic, 2006: 30). Supply chain strategies are pivotal to the success of most contemporary businesses and equally important for not-for-profit organisations (Hines, 2006: 32). Strategies exist, whether they are planned or not. In other words all organisations have a de facto strategy. To be effective, an organisation's supply chain strategy must align with its competitive strategy (Chopra \& Meindl, 2010: 37).

\section{Types of supply chain strategies}

There are two generic strategies in supply chain management, namely the lean and agile strategies (Hull, 2005; Simons \& Zokaei, 2005; Hallgren \& Olhager, 2009; Pandey \& Garg, 2009; Vinodh, Sundararaj \& Devadasan, 2009). Here, 'leanness means developing a value stream to eliminate all waste, including time, and to enable a level schedule', while 'agility means using market knowledge and a virtual corporation to exploit profitable opportunities in a volatile marketplace' (Manson-Jones et al., 2000: 54). 


\section{The lean supply chain strategy}

Lean is a supply chain term defined as the 'enhancement of value by the elimination of waste' (Womack \& Jones, 2003). A lean supply chain is concerned with cost reduction by operating the basic processes with a minimum of waste (Qi et al., 2009: 670). The primary objective of a lean supply chain can be realised by using the most basic forms of data communication on inventories, capacities, and delivery plans and fluctuations within the framework of just-in-time (JIT) principles (Amir, 2011: 288; El-Tawy \& Gallear, 2011: 817). Some of the key features of a lean supply chain strategy are predictable market demand; a lowest-price criterion; product supply based on forecasts; a long product life cycle; and long order lead time (Gattorna, 2006: 136). Customers in lean supply chains are delivered value through 'low production cost and logistics achieved by using all available synergies and economies of scale' (Gattorna, 2006: 138). Many organisations have successfully implemented and are benefiting from lean strategies (Gurumurthy \& Kodali, 2009: 274; Duarte \& Machado, 2011: 330). Despite the benefits associated with lean strategies, they have been criticised as lacking in human integration and being characterised by repetitive manufacturing (Hines, Holweg \& Rich, 2004: 994; Duarte \& Machado, 2011: 330). As a result, many prefer an agile supply chain strategy or a combination of both strategies.

\section{Agile supply chain strategy}

Agility is a comprehensive response to the business challenges of profiting from rapidly changing, continually fragmenting global markets for high-quality, high-performance, customer-configured goods and services (Iskanius, 2006: 93). The main objectives of agility are based on competition, business practice, corporate structures in the 21st century, strategic response, adaptability, building defences against competitors, a paradigm shift, a step towards innovation, and the promise of a business world based around cooperation (El-Tawy \& Gallear, 2011: 819). Hence, agility is an appropriate strategy when coping with turbulence and reconfiguring operations to enable individual customer specifications to be accommodated in high-volume manufacturing. Baker (2008: 28) advocated that agility not only responds to changing market conditions, but also to exploiting changing opportunities (Li, Chung, Goldsby \& Holsapple, 2008: 410).

Agility was applied to supply chains to transfer the winning strategy and benefits of agility to supply chains (Rahimnia, Moghadasian \& Castka, 2009: 801). Agility in the context of SCM focuses on 'Responsiveness' (Christopher \& Towill, 2002: 2). Li et al. (2008: 408) professed that, in today's complex and challenging supply chains, agility is critical to global competitiveness. Agility in a supply chain, according to Ismail and Sharifi (2006: 432), is the ability of the supply chain as a whole, and its members, to rapidly align the network and its operations to dynamic and turbulent requirements of the customers (Duarte \& Machado, 2011: 331). The main focus is on running businesses in network structures with an adequate level of agility to respond to changes while proactively anticipating changes and seeking 
new emerging opportunities (Sharifi, Ismail \& Reid, 2006: 1080). Agility measures how well the relationships involved in the processes can be enhanced and widely accepted as a winning strategy for growth (Ismail \& Sharifi, 2006: 432). The key elements of an agile supply chain include (Ismail \& Sharifi, 2006: 433; Gunasekaran, Lai \& Cheng, 2008: 553): being information driven (or virtual); having market sensitivity (or demand-driven); having integrated processes; and being network-based (Amir, 2011: 287).

\section{Leagile supply chain}

A leagile supply chain is a hybrid of lean and agile systems. This system can be defined as 'a system in which the advantages of leaness and agility are combined' (Krishnamurthy \& Yauch, 2007: 591). Leagile supply chains aim to infuse competitiveness in an organisation in a cost-effective manner (Amir, 2011: 290). The combination of lean and agile paradigms within a total supply chain strategy enable the positioning of the decoupling point so as to best respond to a volatile demand downstream, yet still provide a level schedule upstream from the decoupling point (Hull, 2005: 230; Vinodh et al., 2009: 573; Rahimnia \& Moghadasian, 2010: 81). The transition from lean or agile to an integrated leagile supply chain can be interpreted by using an integrated approach to supply chain design, in which the real focus of supply chain re-engineering is on seeking ways to achieve the appropriate combination of lean and agile strategies (Hull, 2005: 230; Mistry, 2005: 104). In this hybrid strategy, lean focuses on waste elimination, achieving low-cost delivery of a standardised and stable product, while agility responds to complexity brought about by constant and unpredicted changes (Duarte \& Machado, 2011: 334).

\section{FACTORS FOR DETERMINING AN OPTIMAL SUPPLY CHAIN STRATEGY}

This section of the article presents the factors that need to be considered when determining an optimal supply chain strategy. The factors are categorised into three groups: the characteristics of the product; the manufacturing characteristics; and the decision drivers of supply chains, as explained below.

\section{Supply chain strategy and the product}

Understanding of the customer and market uncertainty, functional and innovative attributes, the product life cycle, and the market winner are essential when determining the relationship between product characteristics and supply chain strategies.

\section{The customer and market uncertainty}

Customers today are more demanding, not just for quality, but also for service (Sahay, Gupta \& Mohan, 2006: 16). Therefore, for an organisation to choose the right type of supply chain strategy, it must understand the customer and the supply chain uncertainty (Hines, 2006: 57; Chopra \& Meindl, 2010: 41). Within the supply chain environment, there are six key market 
variables that determine the attributes of a supply chain structure: volume; time; variety; service level required; price; and rate of change, innovation, and new product development (Hines, 2006: 58). Fawcett et al. (2007: 222) and Chopra and Meindl (2010: 41) noted that, to be able to understand the customer and market uncertainty, it is important to identify customer segments to determine similarities between groups of customers so that their needs can be satisfied efficiently (Hines, 2006: 58). Customers in different segments may have similar needs to other segments, but in most cases, the differences will be greater than the similarities (Chopra \& Meindl, 2010: 44).

Supply chain uncertainty is strongly affected by the product life cycle of a product (Qi et al., 2009: 670). New products being introduced have higher supply uncertainty. This is because design and production processes are still evolving. Mature products have less supply uncertainty (Hines, 2006: 60; Chopra \& Meindl, 2010: 43).

\section{Functional versus innovative products}

Fisher developed a framework to help managers understand the nature of their product and devised a supply chain that can best satisfy that demand (Jacobs, Chase \& Aquilano, 2009: 362). According to Lee (2002: 106), Selldin \& Olhager (2007: 43), and Jacobs et al., (2009: 362), and based on Fisher's (1997: 105) framework, products can be categorised as either primarily functional or primarily innovative. Functional products are stable, have predictable demand, long life cycles, and low profit margins (Jonsson, 2008: 383; Sanderson \& Cox, 2008: 17; Jacobs et al., 2009: 362; Stavrulaki \& Davis, 2010: 129). In contrast, innovative products are those that compete through their design or on the basis of a unique concept (Jacobs et al., 2009: 263). These products tend to have short life cycles, high profit margins and greater variety, which further increases unpredictability (Jonsson, 2008: 384; Sanderson \& Cox, 2008: 17; Jacobs et al., 2009: 363).

\section{Product life cycle}

It may be difficult to know which strategy to use in a supply chain, but Chibba (2007) explains that using the product life cycle (PLC) theory can help managers identify which strategies to use during different phases of the product cycle (Astrom \& Ohgren, 2010: 21). PLC summarises all the steps from the product design and development phases to the decision to remove it from the market. The product goes through an introduction, growth, maturity and a declining phase (Aitken, Childerhouse \& Towill, 2003: 135; Fawcett et al., 2007: 228; Astrom \& Ohgren, 2010: 21). Figure 1 illustrates how the PLC relates to different supply chain strategies. 


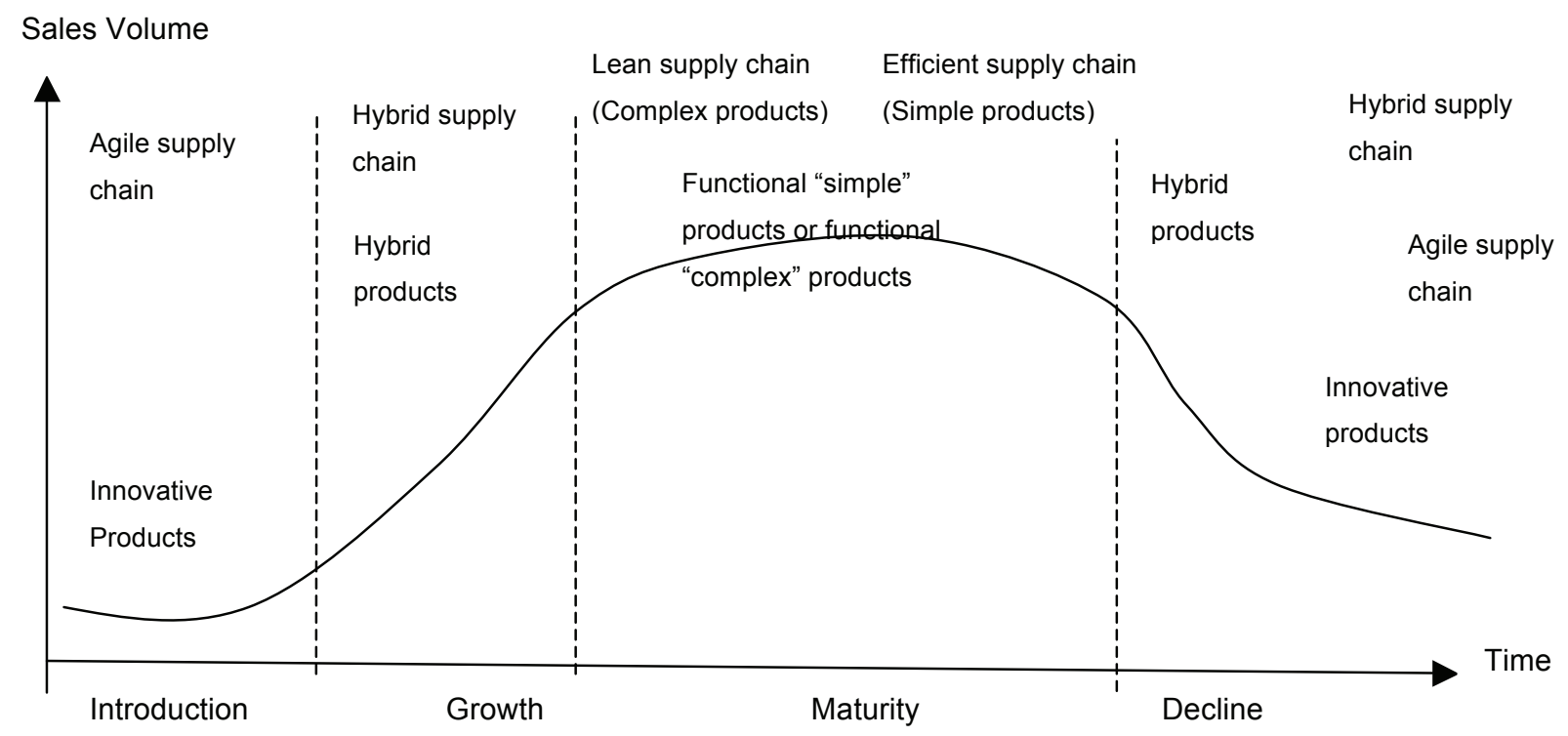

Figure 1: Supply chain strategies linked to the product life cycle Source: Chibba (2007); Astrom and Ohgren (2010:22); Qi et al. (2009:670)

As described in Figure 1, different types of products, i.e., innovative, hybrid or functional, can be classified into different phases of the PLC (Chibba, 2007).

\section{Market winners and market qualifiers}

The concept of 'order qualifiers' and 'order winners' advocates the basis on which manufacturing strategies to choose (Christopher \& Towill, 2002). Order qualifiers form the baseline for entering into a competitive arena, while order winners refer to the specific capabilities that an organisation has to actually win orders (Astrom \& Ohgren, 2010: 24). The concept of order qualifiers and order winners leads to the specification of an appropriate manufacturing strategy. According to Jacobs et al. (2009: 25) qualifiers are the basic criteria that permit a firm's product to be considered as a candidate for purchase by customers; while order winners are the criteria that win an order (they differentiate the products and services of one firm from another). It is from these that the concepts of 'market qualifiers' and 'market winners' developed. The notion here is that to be truly competitive requires not just an appropriate manufacturing strategy but also an appropriate holistic supply chain strategy. There is a critical connection between the concepts of 'qualifiers' and 'winners' and 'lean' and 'agility'. The lean paradigm is most powerful when the winning criterion is cost. However, when service and customer value enhancement are prime requirements for market winning, then it is likely that agility will become the critical dimension.

Table 1 illustrates the crucial differences in focus between the lean and agile paradigms, depending on the market qualifiers and the market winners (Mason-Jones et al. 2000: 55). 
Table 1: Market qualifiers and market winners

\begin{tabular}{|l|l|l|}
\hline & Market Winners & Market Qualifiers \\
\hline Agile supply & 1 Quality & 1 Service level \\
& $\begin{array}{l}\text { 2 Cost } \\
3 \text { Lead time }\end{array}$ & \\
\hline Lean supply & $\begin{array}{l}1 \text { Quality } \\
2 \text { Lead time } \\
3 \text { Service level }\end{array}$ & 1 Cost \\
\hline
\end{tabular}

Source: Mason-Jones et al. (2000:4064)

The market winner for agile supply chains is service, while the market winner for lean supply chains is cost (Rahimnia et al., 2009: 801).

\section{Supply chain strategy and the manufacturing environment Manufacturing process}

A manufacturing process can be defined as the use of machine tools and labour to make products for use or sale (Riis, Johansen, Waehrens \& Englyst, 2007: 934). Karlsson and Sköld (2007: 912) advocate that a manufacturing process is a discipline aligned with business strategy and firm positioning. Four common types of manufacturing structures include the job shop, batch process, line flow process, and continuous process (Jacobs et al., 2009: 206; Bowersox, Closs \& Cooper, 2010: 86; Stavrulaki \& Davis, 2010: 129), as described below:

- Job shop process: Job shop products are typically customised for a specific customer.

- Batch process: Jacobs et al. (2009: 206) define this as the area in which products that are similar in processing requirements are produced.

- Line flow process: As noted by Bowersox et al. (2010: 86), in line processes, products with similar variations are typically used on assembly lines through various stages of production. Processes or components are added at each stage.

- Continuous process: These are similar to assembly lines (line flow processes) in that the product follows a predetermined sequence of steps, but here the flow is continuous (Jacobs et al., 2009: 206: Bowersox et al., 2010: 87).

The relationships between layout structures in a manufacturing process are often depicted on a product-process matrix (Jacobs et al., 2009: 207). The format for the arrangement of facilities begins with the project. In the project layout, the product remains in a fixed location. As indicated in Figure 2, the horizontal axis shows the volume of the product produced, while the vertical axis relates to standardisation. These variations are measured in terms of geometric differences, material differences, and so on. Standardised products 
are highly similar from a manufacturing processing point of view, whereas non-standardised products require different processes. Figure 2 shows the product-process matrix describing the layout for different manufacturing strategies. Project and work centre has low product volume and low level of standardisation, therefore an agile supply chain strategy. With assembly lines and continuous processes, a lean supply chain strategy will be appropriate.

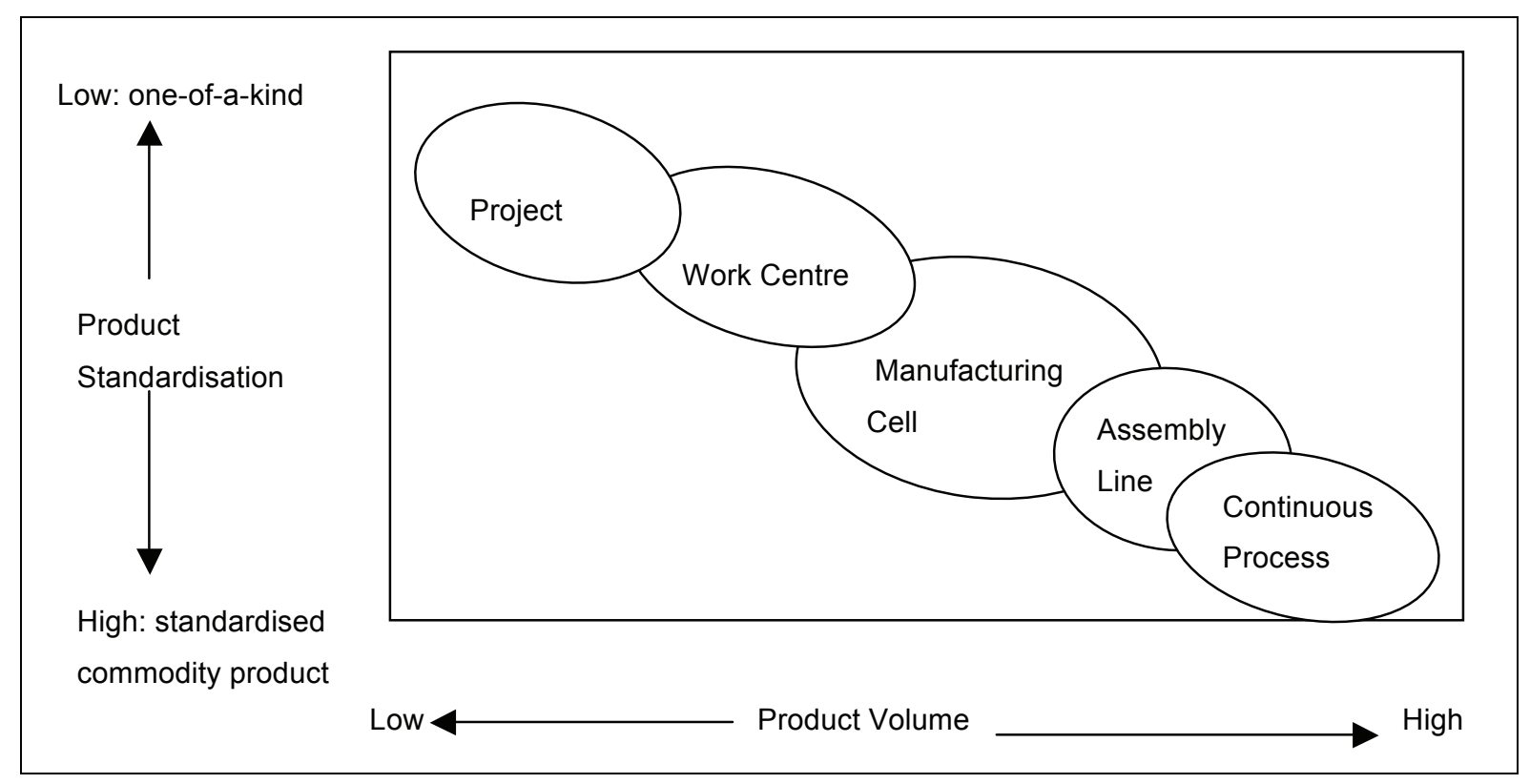

Figure 2: Product-process matrix: framework describing layout strategies Source: Jacobs et al (2009:207); Stavrulaki and Davis (2010:129)

\section{Manufacturing techniques}

The most common manufacturing strategies are make-to-stock, make-to-order, configureto-order, and engineer-to-order (Taylor, 2004: 28; Cohen \& Rousell, 2005: 12; Webster, 2008: 218; and Bowersox et al., 2010: 87). Make-to-stock (MTS) is the best strategy for standardised products that sell in high volumes (Cohen \& Rousell, 2005: 11). According to Cohen and Rousell (2005: 11), make-to-order (MTO) is the preferred strategy for customised products or products with infrequent demand. Companies following this strategy produce a shippable product only with a customer order in hand (Taylor, 2004: 28; Webster, 2008: 219; Bowersox et al., 2010: 87). Configure-to-order (CTO) is a hybrid strategy in which a product is partially completed to a generic level, and then finished when the order is received (Cohen \& Rousell, 2005: 11). This is the preferred strategy when there are many variations to the end product, and the manufacturer wants a lower finished-goods inventory and shorter customer lead time than make-to-order can deliver (Taylor, 2004: 28; Webster, 2008: 219). Bowersox et al. (2010: 87) called this strategy 'assemble-to-order'. Engineer-toorder (ETO) shares many of the characteristics of make-to-order (Cohen \& Rousell, 2005: 11). This strategy is used in industries in which complex products and services are created to unique customer specifications (Webster, 2008: 218). 
Manufacturing strategies clearly have a significant impact on the lead time experienced by customers. The choice of MTS, MTO, CTO or ETO determines whether a customer will bear the cost of waiting for the completion of one or more of the products (Bowersox et al., 2010: 88). As professed by Bowersox et al. (2010: 88), each manufacturing process is associated with different levels of product variety, volume produced, strategy, and the resulting impact on customers in terms of expected lead times. Table 2 shows the link between the different manufacturing processes and each of these factors. As indicated above, the line and continuous flow process will follow a lean supply chain strategy due to limited variety and high volume; while job shop and batch processes will follow an agile supply chain strategy.

Table 2: Linking the manufacturing processes and factors

\begin{tabular}{|l|l|l|l|l|}
\hline & Product variety & Volume & Strategy & Customer lead-time \\
\hline Job shop & Very high & Very low & MTO & Very long \\
\hline Batch & High & Low & MTO/ETO & Long \\
\hline Line flow & Limited & High & ETO/MTS & Short \\
\hline Continuous flow & Very limited & Very high & MTS & Very short \\
\hline
\end{tabular}

Source: Bowersox et al. (2010:89); Jacobs et al. (2010:207); Stavrulaki and Davis (2010:129)

\section{Production process}

There are two main cycles of production strategy in a manufacturing environment, namely mass production and mass customisation (Zhang \& Chen, 2006: 670). Mass production relies heavily on a company's ability to accurately forecast demand. These forecasts guide the organisation's decision regarding operations and production (Zhang \& Chen, 2006: 668). Customisation is the result of a new product (model) and is what enable firms to capture the efficiency advantages of mass production (Joubert \& Bekker, 2003: 98; Vollman, Berry, Whybark \& Jacobs, 2005: 615). Mass production is built towards forecast-driven production and employs a lean supply chain strategy, while mass customisation is built towards customer-driven production and employs an agile supply chain strategy (Zhang \& Chen, 2006: 668).

\section{Push and pull supply}

Simchi-Levi et al. (2003) distinguish between supply chains in which the flow is triggered by actual demand signals (pull-based supply chains), a forecast of future demand (push-based supply chains), and hybrid approaches (Diaz, 2005: 65). Push-based supply chains cater to stable demand of homogenised products (lean supply chain strategy), whereas production and distribution decisions are based on long-term forecasts. In the pull-based supply chain, 
the entire supply chain is driven by actual demand (agile supply chain strategy). Here, the time to market becomes long, depending on the type of supply chain and the number of players involved (Diaz, 2005: 66).

\section{Supply chain strategy and decision drivers of supply chains}

SCM emphasises the relationships between partners in the supply chain, integrating activities from the supplier to the customer while adding value, maximising profitability through efficiency, and achieving satisfaction (Sayuti, 2011: 287). Effective supply chain management calls for an understanding of each driver and how it operates. Decision drivers directly affect the supply chain strategic choice. These decision drivers include integration, collaborative relationships, information technology, production/facilities, inventory decisions, sourcing decisions, location decisions, transportation and pricing.

\section{Supply chain integration}

Organisations need to manage the integration of business, technology and processes across extended enterprises to be successful (Awad \& Nassar, 2010). An integrated supply chain improves customer satisfaction and loyalty, as customers experience better on-time delivery. As noted by El-Tawy and Gallear (2011: 824), the integration process for a lean supply chain requires integrated research and design processes that ensure a two-way communication between the manufacturer-supplier and manufacturer-customer. In the case of an agile supply chain, integration ensures a comprehensive communication between parties of the supply chain, with self-sufficient module systems that are easy to re-use (Duarte \& Machado, 2011: 337). Sayuti (2011: 288) noted that the integration process for an agile supply chain should be more rapid than that of a lean supply chain. Duarte and Machado (2011: 330) believe that the key enabler for an agile supply chain is the integration of business partners to enable a rapid response to changing and fragmented markets.

\section{Information technology}

Technology enables help supply chain members to establish partnerships for better supply chain performance (Fawcett et al., 2007: 376; Jain, Dangayach \& Agarwal, 2011: 200). Accurate and timely information allows a firm to minimise inventories, improve routing and scheduling of transportation vehicles, and generally improve customer service levels (Barve, 2011: 326). Modern information technology makes possible the fast and safe transmission and processing of extensive amounts of data, both internally for users within the company, and externally for suppliers and customers (Shukla et al. 2011: 2064). High levels of responsiveness can be achieved when companies collect and share accurate and timely data generated by operations (Nel \& Badenhorst-Weiss, 2010: 211). According to Duarte and Machado (2011: 330), end-to-end visibility of information is a key enabler for an agile supply chain. 


\section{Collaborative relationships}

Collaborative relationships among supply chain members enable different people and organisations to support each other by leveraging, combining and capitalising on their complementary strengths and capabilities (Christopher, 2005: 201; Bowersox et al., 2010: 9; Sayuti, 2011: 288). According Sayuti (2011: 288), the way in which relationships are managed among supply chain members depends on whether it is an agile or lean supply chain. In an agile supply chain, collaboration should be better. Establishing better relationships with supply chain partners could improve the agility of the supply chain (Duarte \& Machado, 2011: 330).

\section{Production (facilities)}

The fundamental decision that managers face when making production decisions is how to resolve the trade-off between responsiveness and efficiency (Taylor, 2004: 21). If factories and warehouses are built with a lot of excess capacity, they can be very flexible and respond quickly to swings in product demand (Nel \& Badenhorst-Weiss, 2010: 211). Facilities where all, or almost all, capacity is being used are not capable of responding easily to fluctuations in demand. In contrast, capacity costs money, and excess capacity is idle capacity not in use and not generating revenue. So the more excess capacity there is, the less efficient the operation becomes (Ambe \& Badenhorst-Weiss, 2011: 340).

\section{Inventory}

Managers must decide where they want to position themselves in the trade-off between responsiveness and efficiency (Nel \& Badenhorst-Weiss, 2010: 210). Holding large amounts of inventory allows a company or an entire supply chain to be very responsive to fluctuations in customer demand (Bowersox et al., 2010: 157). However, creating and storing inventory is a cost and to achieve high levels of efficiency, the cost of inventory should be kept as low as possible. An organisation can be responsive by stocking high levels of inventory for a wide range of products (Chopra \& Meindl, 2010: 65).

\section{Location}

Location refers to where supply chain facilities are geographically located (Jonsson, 2008: 53). It also includes the decisions related to which activities should be performed in each facility. The responsiveness versus efficiency trade-off here is whether to centralise activities in fewer locations to gain economies of scale and efficiency, or to decentralise activities in many locations to be closer to customers and suppliers and so be more responsive. When making location decisions, managers need to consider a range of factors that relate to a given location, including the cost of facilities, the cost of labour, skills available in the workforce, infrastructure conditions, taxes and tariffs, and proximity to suppliers and customers. Location decisions tend to be very strategic decisions because they commit large amounts of money to long-term plans (Nel \& Badenhorst-Weiss, 2010: 211). Location 
decisions have a strong impact on the cost and performance characteristics of a supply chain. Once the size, number and location of facilities are determined, this also defines the number of possible paths through which products can flow on the way to the final customer (Chopra \& Meindl, 2010: 63).

\section{Transportation}

Transportation refers to the movement of everything from raw materials to finished goods between different facilities in a supply chain (Jonsson, 2008: 63). In terms of transportation, the trade-off between responsiveness and efficiency is manifested in the choice of transport mode (Taylor, 2004: 23). Fast modes of transport, such as aeroplanes, are very responsive but also more costly. Slower modes, such as ship and rail, are very cost efficient but not as responsive. Since transportation costs can be as much as a third of the overall operating cost of a supply chain, these decisions are very important (Jonsson, 2008: 64; Nel \& BadenhorstWeiss, 2010: 211).

\section{Sourcing}

Sourcing refers to the set of business processes required to purchase goods and services (Hines, 2006: 177; Jonsson, 2008: 164). Sourcing decisions are crucial because they affect the level of efficiency and responsiveness the supply chain can achieve. Outsourcing certain processes to other parties may increase a supply chain's efficiency, but may reduce its responsiveness because of possibly longer lead times to achieve economies of scale ( $\mathrm{Nel}$ \& Badenhorst-Weiss, 2010: 211). In contrast, responsiveness can be increased by gaining state-of-the-art products. Outsourcing decisions should be driven by a desire for growth in total supply chain surplus (Chopra \& Meindl, 2010: 73).

\section{Pricing}

Pricing is the process by which a firm decides how much to charge customers for its goods and services. Pricing affects the customer segments that choose to buy the product, as well as customer expectations. This directly affects the supply chain in terms of the level of responsiveness required, as well the demand profile that the supply chain attempts to serve (Chopra \& Meindl, 2010: 74). Pricing is a significant attribute through which firms execute a competitive strategy. Customers expect low prices but tend to be comfortable with a lower level of product availability. Steady prices also ensure that demand stays relatively stable. Therefore, pricing affects the behaviour of the buyer of the product, thus affecting supply chain performance. Customers who value responsiveness will pay more for higher levels of customer service (Nel \& Badenhorst-Weiss, 2010: 211).

\section{COMPREHENSIVE FRAMEWORK FOR SUPPLY CHAIN STRATEGIES}

Based on the discussion provided above, there are several factors that can be considered when determining an optimal supply chain strategy. There are three groups of factors: 
product characteristics; manufacturing characteristics; and decision drivers. As indicated in Table 3 and Table 4, most studies have concentrated on product characteristics when determining a supply chain strategy, followed by manufacturing characteristics.

Table 3: Determinant factors for supply chain strategies

\begin{tabular}{|l|l|}
\hline Determining factor & Authors \\
\hline Product characteristics & Fisher (1997); Naylor et al. (199); Lee (2002); Mason-Jones et \\
al. (2000); Lo and Power (xx); Christopher and Towill (2000); \\
Christopher and Peck (2004); Astrom and Ohgren (2010); \\
Chibba (2007); Hines (2006); Sun et al (2009); Vinodh et al. \\
(2009); Simch-Levi et al. (2003); Misty (2005); Jacobs et al. \\
(2009); Rahiminia and Moghadasian (2010); Zhan and Chen \\
(2006); Agarwal et al. (2006); Chopra and Meindl (2010); \\
Bowersox et al. (2010); Stavrulaki and David (2010); Qi et al. \\
(2011); Amir (2011); El-Tawy and Gallear (2011); Duarte and \\
Machado (2011)
\end{tabular}

Source: Author

Decision drivers are the least-mentioned criteria in research studies (see Table 3). Therefore, it is important to map the various determinants in a framework so that future studies can empirically test these variables. Table 4 shows a comprehensive framework for determining supply chain strategies. 
Table 4: Comprehensive framework for determining supply chain strategies and practices

\begin{tabular}{|c|c|c|c|}
\hline Criteria & Description of criteria & Lean supply chain & Agile supply chain \\
\hline \multirow{7}{*}{ 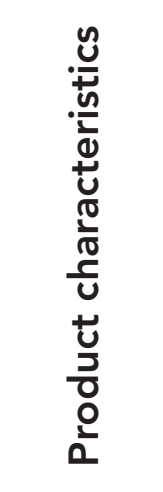 } & Demand uncertainty & Predictable & Unpredictable \\
\hline & Product type & Functional products & Innovative products \\
\hline & Profit margin & Low & High \\
\hline & Product variety & Low & High \\
\hline & Order lead-time & Long & Short \\
\hline & Market winner & Cost & Availability \\
\hline & Product life cycle & Long & Short \\
\hline \multirow{6}{*}{ 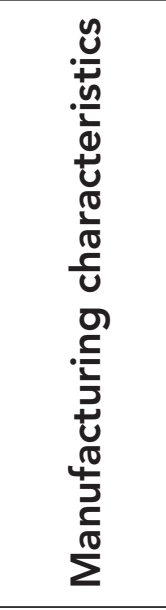 } & Market segment & $\begin{array}{l}\text { Serve only current market } \\
\text { segment }\end{array}$ & $\begin{array}{l}\text { Develop new product } \\
\text { lines and open up new } \\
\text { markets }\end{array}$ \\
\hline & Manufacturing focus & $\begin{array}{l}\text { Maintain high average } \\
\text { utilisation rate }\end{array}$ & $\begin{array}{l}\text { Deploy excess buffer } \\
\text { capacity }\end{array}$ \\
\hline & Manufacturing process & $\begin{array}{l}\text { Continuous (large } \\
\text { volume) }\end{array}$ & Job shop; batch; line flow \\
\hline & Production process & $\begin{array}{l}\text { Standardised product } \\
\text { (Mass production) }\end{array}$ & Customised products \\
\hline & Techniques & MTS & MTO; ETO \\
\hline & Approach & Push-based system & Pull-based system \\
\hline \multirow{9}{*}{ 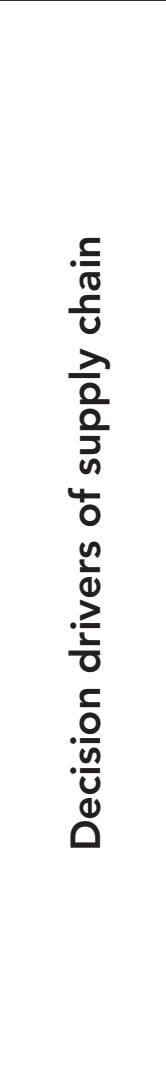 } & Integration & $\begin{array}{l}\text { Integrate manufacturing, } \\
\text { purchasing, quality, and } \\
\text { suppliers }\end{array}$ & $\begin{array}{l}\text { Integrate marketing, } \\
\text { engineering, distribution, } \\
\text { and information systems }\end{array}$ \\
\hline & $\begin{array}{l}\text { Collaborative } \\
\text { relationships }\end{array}$ & $\begin{array}{l}\text { High information sharing; } \\
\text { traditional alliances }\end{array}$ & $\begin{array}{l}\text { More collaborative } \\
\text { barriers; visual } \\
\text { organisation }\end{array}$ \\
\hline & Information technology & $\begin{array}{l}\text { Highly desirable; cost of } \\
\text { information drops while } \\
\text { other costs rise }\end{array}$ & $\begin{array}{l}\text { Obligatory; collect and } \\
\text { share timely, accurate } \\
\text { data }\end{array}$ \\
\hline & Facilities & $\begin{array}{l}\text { Narrow focus; few } \\
\text { centralised plants }\end{array}$ & $\begin{array}{l}\text { Flexible manufacturing; } \\
\text { many small factories }\end{array}$ \\
\hline & Inventory & $\begin{array}{l}\text { Low inventory levels; few } \\
\text { items }\end{array}$ & High inventory levels \\
\hline & Location & Few central locations & Many locations \\
\hline & Transportation & $\begin{array}{l}\text { Shipments are few and in } \\
\text { large quantities }\end{array}$ & Frequent shipments \\
\hline & Sourcing & $\begin{array}{l}\text { Supplier attributes } \\
\text { include low costs and } \\
\text { high quality }\end{array}$ & $\begin{array}{l}\text { Supplier attributes } \\
\text { involve speed, flexibility, } \\
\text { and quality }\end{array}$ \\
\hline & Pricing & Price based on volume & Price based on margins \\
\hline
\end{tabular}




\section{CONCLUSION}

Given the complexity in satisfying customers' demands, there is a need for different supply chain strategies to be developed for different product lines. Two primary generic and accepted strategies in the supply chain are lean and agile supply chains. A combination of the attributes of lean and agile supply chains gives a strategy known as a leagile supply chain. Literature reveals that there are various factors that can be considered when determining supply chain strategies (leanness and agility). However, the majority of studies have emphasised product characteristics over other characteristics. Apart from product characteristics, factors such as core competencies of the organisation, the capabilities of the supply chain members and decision drivers are significant criteria that need to be considered. Hence, there is a need for a comprehensive framework that incorporates the various aspects of determining an optimal supply chain strategy.

The purpose of this article was to suggest instruments for determining an optimal supply chain strategy. The methodology for the article was based on a theoretical analytical approach. In the course of the article, related reviews on supply chain strategy were examined. The purpose of the review was to illustrate the status of supply chain strategies and to point out the various criteria that can be used to determine an optimal strategy. Finally, the paper presented a comprehensive framework containing appropriate supply chain instruments for different strategies. Here, the different characteristics and practices for lean and agile supply chain strategies were mapped out in a comprehensive framework. From the literature review, the supply chain characteristics were divided into three categories within the framework: product characteristics; manufacturing characteristics; and decision drivers.

With respect to product characteristics, variables such as demand uncertainty, product type, profit margin, product variety, order lead time, market winners, product life cycle, and so on all need to be considered. Important manufacturing characteristics include the market segment, the manufacturing focus, the processes and the techniques (MTS, MTO, ETO and CTO). Finally, decision drivers include tools such as integration, collaborative relationships, information technology, facilities, inventory, location, transportation, sourcing strategy and pricing strategy. 


\section{REFERENCES}

Agarwal, A., Shankar, R. \& Tiwari, M.K. 2007. Modeling agility of supply chains. Industrial Marketing Management, 36: 443-57.

Aitken, J., Childerhouse, P., \& Towill, D. 2003. The impact of product life cycle on supply chain strategy. International Journal of Production Economics, 85: 127-40.

Ambe, I.M., Badenhorst-Weiss, J.A. 2011. South African automotive industry: trends and challenges in the supply chain. Journal of Contemporary Management, 8: 337-362.

Amir, F. 2011. Significance of lean, agile and leagile decoupling point in supply chain management. Journal of Economics and Behavioural Studies, 3(5): 287-95.

Astrom, E. \& Ohgren, M. 2010. Evaluating distribution centres in a global supply chain: A case study at Cargotec Sweden, MacGregor Cranes. Master's thesis, Lulea University of Technology.

Awad, H.A.H. \& Nassar, M.O. 2010. Supply chain integration: Definition and challenges. Proceedings of the International MultiConference of Engineers and Computer Scientists, vol.1, IMECS, 2010, March 17-19, Hong Kong.

Baker, P. 2008. The design and operation of distribution centres within agile supply chains. International Journal of Production Economics, 111(1): 27-41.

Barve, A. 2011. Impact of supply chain agility on customer satisfaction. International Conference on E-business, Management and Economics, IPEDR vol.3 (2011), IACSIT Press, Hong Kong.

Botha, M.E. 1989. Theory development in perspective: The role of conceptual frameworks and models in theory development. Journal of Advanced Nursing, 14(1): 49-55.

Bowersox, D.J., Closs, D.J. \& Cooper, M.B. 2010. Supply chain logistics management. 3rd edition, Singapore: McGraw-Hill.

Chibba, A. 2007. Measuring supply chain performance measures - prioritising performance measures. Licentiate thesis. Division of Industrial management. Lulea University of Technology.

Chopra, S. \& Meindl, P. 2010. Supply chain management: Strategy, planning and operation. Upper Saddle River, New Jersey: Pearson. 
Christopher, M. \& Towill, D.R. 2001. An integrated model for the design of agile supply chains. International Journal Physical Distribution \& Logistics, 31(4): 234-46.

Christopher, M. \& Towill, D.R. 2002. Developing market-specific supply chain strategies. International Journal of Logistics Management, 13(1): 1-14.

Christopher, M. 2005. Logistics and supply chain management: Creating value-added networks. Harlow, England: Prentice Hall.

Christopher, M., Peck, H., Towill D. 2006. A taxonomy for selecting global supply chain strategies. International Journal of Logistics Management, 17(2): 277-87.

Cohen, S. \& Rousell, J. 2005. Strategic supply chain management: The five disciplines for top performance. New York: McGraw-Hill.

Diaz, F.C. 2005. An integrative framework for architecting supply chains. Master's thesis, Massachusetts Institute of Technology, Madrid, 2005.

Duarte, S. \& Machado, V.C. 2011. Manufacturing paradigms in supply chain management. International Journal of Management Science and Engineering Management, 6(5): 328-42.

El-Tawy, N. \& Gallear, D. 2011. Leanness and agility as means for improving supply chains: A case study on Egypt. European, Mediterranean and Middle East Conference on Information Systems, 809-41.

Fawcett, S.E., Ellram, L.M. \& Ogden, J.A. 2007. Supply chain management: From vision to implementation. Upper Saddle River, New Jersey: Prentice Hall.

Fisher, M.L. 1997. What is the right supply chain for your product? Harvard Business Review, 105-16.

Gattorna, J. 2006. Living supply chains: How to mobilize the enterprise around delivering what your customers want. Prentice Hall.

Gunasekaran, A., Lai, K-H. \& Cheng, T.C.E. 2008. Responsive supply chain: A competitive strategy in a networked economy. International Journal of Management Science, 36(4): 549-64.

Gurumurthy, A. \& Kodali R. 2009. Application of benchmarking for assessing the lean manufacturing implementation. Benchmarking: An International Journal, 16(2): 274-308. 
Hallgren, M. \& Olhager, J. 2009. Lean and agile manufacturing: external and internal drivers and performance outcomes. International Journal of Operations \& Production Management, 29(10): 976-99.

Handfield, R.B., Monczka, R.M., Giuinipero, L.C. and Patterson, J.L. 2009. Sourcing and supply chain management. 4th edition. Ontario: Southern Western.

Hilletofth, P. 2009. How to develop a differentiated supply chain strategy. Industrial Management and Data Systems, 109(1): 16-33.

Hines, P., Holweg, M. \& Rich, N. 2004. Learning to evolve. A review of contemporary lean thinking. International Journal of Operations \& Production Management, 24(10): 994-1011.

Hines, T. 2006. Supply chain strategies: Customer-driven and customer focused. Boston: Elsevier.

Hugo, W.M.J., Badenhorst-Weiss J.A. \& Van Biljon E.H.B. 2011. Supply chain management: logistics in perspective. 5rd edition, Pretoria: Van Schaik.

Hull, B.Z. 2005. Are supply (driven) chains forgetting? The International Journal of Logistics Management, 16(2): 218-36.

Iskanius, P. 2006. An agile supply chain for a project-oriented steel product network. Available from http:www.herkules.oulu.fi/isbn9574281489 (Accessed 1 July 2008).

Ismail, H.S., Sharifi, H. 2006. A balanced approach to building agile supply chains. International Journal of Physical Distribution and Logistics Management, 26(6) 431-44.

Jacobs, F.R., Chase, R.B. \& Aquilano, N.J. 2009. Operations and supply management. 12th edition, United States: McGraw-Hill.

Jain, J.K., Dangayach, G.S. \& Agarwal, G. 2011. Evidence of Supply Chain Management in Indian manufacturing firms: a survey. International Journal of Management Science and Engineering Management, 6(3): 198-209.

Jonsson, P. 2008. Logistics and supply chain management. McGraw-Hill, UK.

Joubert, F.J. \& Bekker, M.C. 2003. The impact of mass customization on the quality of management system in a sale and marketing environment-A case study. South African Journal of Industrial Engineering, 14(2):97-107. 
Karlsson, C. \& Sköld, M. 2007. The manufacturing extraprise: an emerging production network paradigm. Journal of Manufacturing Technology Management, 18(8): 912-32.

Klemencic, E. 2006. Management of supply chain: Case of Danfoss District Heating business area. Faculty of Economics, Ljubljana University, February 2006.

Krishnamurthy, R. \& Yauch, C.A. 2007. Leagile manufacturing: a proposed corporate infrastructure. International Journal of Operations \& Production Management, 27(6): 588-604.

Lee, H.L. 2002. Aligning supply chain strategies with product uncertainties. California Management Review, 44: 105-119.

Li, X., Chung, C., Goldsby, T.J. \& Holsapple, C.W. 2008. A unified model of supply chain agility: the work-design perspective. The International Journal of Logistics Management, 19(3): 408-35.

Mason-Jones, R., Naylor, B. \& Towill, D.R. 2000. Engineering the leagile supply chain. International Journal of Agile Management Systems. 2(1): 54-61.

Mistry, J.J. 2005. Supply chain management: A case study of an integrated lean and agile model. QRAM, 2(2).

Narasimhan, R. \& Kim, S.W. 2002. Effect of supply chain integration on the relationship between diversification and performance: Evidence from Japanese and Korean firms. Journal of Operations Management, 20(3): 303-23.

Nel, J.D. \& Badenhorst-Weiss, J.A. 2010. Supply chain design: Some critical questions. Journal of Transport and Supply Chain Management, 4(1): 198-223.

Pandey, V.C.\& Garg, S. 2009. Analysis of interaction among the enablers of agility in supply chain. Journal of Advances in Management Research, 16(1): 99-114.

Qi, Y., Boyer, K.K. \& Zhao, X. 2009. Supply chain strategy, product characteristics, and performance impact: Evidence from Chinese manufacturers. Decision Sciences Journal, 40(4): 667-95.

Qi, Y., Zhao, X. \& Sheu, C. 2011. The impact of competitive strategy and supply chain strategy on business performance: The role of environmental uncertainty. Decision Sciences Journal, 42(2): 371-389. 
Rahimnia, F., Moghadasian, M. \& Castka, P. 2009. Benchmarking leagility in services. The case of fast food restaurant chains in Iran. Benchmarking: An International Journal, 16(6): 799-816.

Rahimnia, F. \& Moghadasian, M. 2010. Supply chain leagility in professional services: how to apply decoupling point concept in healthcare delivery system. Supply Chain Management: An International Journal, 15(1): 80-91.

Riis, J.O., Johansen, J., Waehrens, B.V. \& Englyst, L. 2007. Strategic roles of manufacturing. Journal of Manufacturing Technology Management, 18(8): 933-48.

Sahay, B.S., Gupta, J.N.D, \& Mahan, R. 2006. Managing supply chains for competitiveness: the Indian scenario. Supply Chain Management: An International Journal, 11(1): 15-24.

Sanderson, F. \& Coz, A. 2008. The challenges of supply strategy selection in a project environment: evidence from UK naval shipbuilding. Supply Chain Management: An International Journal, 13(1): 16-25.

Sayuti, N.M. 2011. Critical determinants of agile supply chain in buyer and supplier relationship: A literature review and future direction. International Journal of Business and Management Studies, 3(1): 287-98.

Sebastiao, H.J. \& Golicic, S.L. 2008. Supply Chain Strategy for Nascent Firms in Emerging Technology Markets. Journal of Business Logistics, 21(1): 75-91.

Selldin, E. \& Olhager, J. 2007. Linking products with supply chains: Testing Fisher's model. Supply Chain Management: An International Journal, 12(1): 42-51.

Sharifi, H., Ishmail, H.S. \& Reid, I. 2006. Achieving agility in supply chain through simultaneous 'design of' and 'design for' supply chain. Journal of Manufacturing Technology Management, 17(8): 1078-98.

Shukla, K.R., Garg, D. \& Agarwal, A. 2011. Understanding of supply chain: A literature review. International Journal of Engineering Science and Technology (IJEST), 3(3): 2059-72.

Simchi-Levi, D., Kaminsky, P. \& Simchi-Levi, E. 2003. Designing and managing the supply chain: Concepts, strategies and case studies. Boston: McGraw-Hill.

Simons, D. \& Zokaei, K. 2005. Application of lean paradigm in red meat processing. British food Journal, 107(4): 192-211. 
Stavrulaki, E. \& Davis, M. 2010. Aligning products with supply chain processes and strategy. The International Journal of Logistics Management, 21(1): 127-51.

Taylor, D.A. 2004. Supply chains. A manager's guide. USA: Pearson Education.

Vinodh, S., Sundararaj, G. \& Devadasan, S.R. 2009. Total agile design system model via literature exploration. Industrial Management and Data System, 109(4): 570-88.

Vollman, T.E, Berry, W.L., Whybark, D.C. \& Jacobs, F.R. 2005. Manufacturing planning and control for supply chain management. 5th edition, Singapore: McGraw-Hill.

Webster, S. 2008. Principles and tools for supply chain management. USA: McGraw-Hill.

Womack, J.P. \& Jones, D.T. 2003. Lean thinking, banish waste and create wealth in our corporation. Free Press.

Yusuf, Y.Y., Gunasekaran, A., Adeleye, E.O. \& Sivayoganathan, K. 2004. Agile supply chain capabilities: Determinants of competitive objectives. European Journal of Operational Research, 159: 379-92.

Zhang, X. \& Chen, RA. 2006. Forecast-driven or customer-order-driven? An empirical analysis of the Chinese automotive industry. International Journal of Operations \& Production Management, 26(6): 668-88. 